\title{
Meningkatkan Hasil Belajara Bahasa Indonesia Materi Teks Eksposisi dalam Media Massa dengan Strategi Buzz Group pada Siswa Kelas VIII SMP Negeri 1 Praya Tahun Pelajaran 2018/2019
}

\author{
Siti Ahadiah Desemyati \\ Guru Bahasa Indonesia SMPN 1 Praya
}

\begin{abstract}
Abstrak. Strategi ini (buzz group), kelas dibagi dalam kelompok-kelompok kecil untuk melakukan diskusi singkat tentang suatu problem. Tiap kelompok di minta untuk menghasilkan suatu hipotesis yang mereka pandang relevan dengan satu penerapan suatu prinsip, contoh suatu konsep, atau dengan suatu solusi terhadap suatu problem. Penelitian ini berdasarkan permasalahan: Bagaiamanakah Meningkatkan Hasil Belajar Bahasa Indonesia Materi Teks Eksposisi dalam Media Masa dengan Strategi Buzz Group pada Siswa Kelas VIII SMPN 1 Praya Tahun Pelajaran 2018/2019?. Tujuan dari penelitian ini adalah: Untuk Meningkatkan Hasil Belajar Bahasa Indonesia Materi Teks Eksposisi dalam Media Masa dengan Strategi Buzz Group pada Siswa Kelas VIII SMPN 1 Praya Tahun Pelajaran 2018/2019 Penelitian ini menggunakan penelitian tindakan (action research) sebanyak tiga putaran. Setiap putaran terdiri dari empat tahap yaitu: rancangan, kegiatan dan pengamatan, refleksi, dan refisi. Sasaran penelitian ini adalah siswa Kelas VIII. Data yang diperoleh berupa hasil tes formatif, lembar observasi kegiatan belajar mengajar. Dari hasil analis didapatkan bahwa prestasi belajar siswa mengalami peningkatan dari siklus I sampai siklus III yaitu, siklus I (62\%), siklus II (77\%), siklus III (90\%). Simpulan dari penelitian ini adalah metode Buzz Group dapat berpengaruh positif terhadap motivasi belajar Siswa Kelas VIII, serta model pembelajaran ini dapat digunakan sebagai salah satu alternative Bahasa Indonesia .
\end{abstract}

Kata Kunci: Buzz Group, Materi Teks Eksposisi, Bahasa Indonesia

\section{PENDAHULUAN}

Latar Belakang Masalah Perkembangan dunia kearah globalisasi telah mengubah dunia tenjadi satu lampung tanpa batas. Dalam situasi demikian, untuk mampu bertahan, setiap negara di tuntut menyiapkan diri agar mampu berkompetensi dengan negara lain di dunia. Kemampuan negara untuk berkompetensi dengan negara lain hanya di miliki jika negara memiliki sumber daya yang unggul. Pendidikan merupakan cara sebuah negara menyiapkan kualitas sumber daya manusia.

Pendidikan menurut UU no. 20 tahun 2003 dapat di artikan sebagai usaha sadar dan terencana untuk mewujudkan suasana belajar dan proses belajar agar peserta didik secara aktif mengembangkan potensi dirinya untuk memiliki kekuatan spiritual keagamaan, pengendalian diri, kepribadian, kecerdasan, akhlak mulia, serta keterampilan yang diperlukan dirinya, masyarakat, bangsa dan negara. Dalam hal ini tentu saja diperlukan adanya pendidikan yang profesional terutama guru disekolah dasar dan menengah serta dosen di perguruan tinggi.

Menurut Bukhori, bahwa pendidikan yang baik adalah pendidikan yang tidak hanya mempersiapkan para siswanya untuk suatu profesi atau jabatan, tetapi untuk menyelesaikan masalah-masalah yang dihadapinya dalam kehidupan sehari-hari.

Salah satu masalah pokok dalam pembelajaran pada pendidikan formal (sekolah) dewasa ini adalah masih rendahnya daya serap peserta didik. Hal ini nampakmerata hasil belajar peserta didik yang senantiasa masih sangat memprihatinkan. Prestasi ini tentunya merupakan hasil kondisi pembelajaran yang masih bersifat konvensional dan tidak menyentuh ranah dimensi peserta didik itu sendiri, yaitu bagaimana sebenarnya belajar itu (belajar untuk belajar). Dalam arti yang 
substansial bahwa proses pembelajaran hingga dewasa ini masih memberikan dominasi guru dan tidak memberikan akses bagi anak didik untuk berkembang secara mandiri melalui penemuan dan proses berfikirnya.

Dalam strategi ini (buzz group), kelas dibagi dalam kelompok-kelompok kecil untuk melakukan diskusi singkat tentang suatu problem. Tiap kelompok di minta untuk menghasilkan suatu hipotesis yang mereka pandang relevan dengan satu penerapan suatu prinsip, contoh suatu konsep, atau dengan suatu solusi terhadap suatu problem.

Langkah-langkah dari strategi ini biasanya dimulai dengan memilih orang yang akan melaporkan hasil diskusi sekaligus memimpin diskusi. Kemudian meminta kepada setiap anggota kelompok untuk mengemukakan suatu ide untuk menjawab pertanyaan atau memecahkan masalah yang di diskusikan. Akhirnya mereka harus menghasilkan satu ide yang di sepakati bersama untuk di laporkan ke kelas besar. Untuk strategi ini biasanya kelompok di beri batasan waktu seperti lima menit, sepuluh menit atau lebih, tergantung kompleksitas masalahnya.

Penggunaan kelompok buzz group memerlukan pengaturan tempat duduk dalam posisi melingkar. Strategi ini menjamin partisipasi semua anggota kelompok.

Diskusi kelompok kecil adalah suatu proses yang teratur dengan melibatkan sekelompok siswa dalam interaksi tatap muka kooperatif yang ptimal dengan tujuan berbagai informasi atau pengalaman, mengambil keputusan atau memecahkan masalah. Dan juga antara siswa dengan siswa dapat berperan aktif terutama dalam komunikasi dan memotivasi pada saat proses belajar mengajar tanpa ada dominasi yang berlebihan dari dua belah pihak. Buzz group adalah salah satu strategi yang bisa memberikan suasana kelas yang baru dalam proses pembelajaran khususnya Bahasa Indonesia , dalam metode pembelajaran ini siswa akan di latih untuk berfikir secara efektif dengan cara bertukar pendapat dengan siswa yang lain, di samping itu berguna untuk meningkatkan motivasi belajar siswa.

$$
\text { Dengan di terapkan strategi }
$$
tersebut,di harapkan pembelajaran berlangsung dengan menyenangkan dan siswa sangat termotivasi, sehingga mereka mampu menilai, mengingat, serta memahami materi yang telah di ajarkan. Karena dalam penggunaan strategi tersebut, siswa juga ikut berperan aktif secara berkelompok (cooperative learning). Atas dorongan inilah siswa akan termotivasi dalam proses belajar mengajar (pembelajaran).

Dari latar belakang masalah tersebut, maka peneliti merasa terdorong untuk mengambil judul “ Meningkatkan Hasil Belajar Bahasa Indonesia Materi Teks Eksposisi dalam Media Masa dengan Strategi Buzz Group pada Siswa Kelas VIII SMPN 1 Praya Tahun Pelajaran 2018/2019"

\section{Rumusan Masalah}

Berdasarkan latar belakang tersenut diatas maka rumusan masalah dalam penelitian ini adalah "Bagaimanakah Meningkatkan Hasil Belajar Bahasa Indonesia Materi Teks Eksposisi dalam Media Masa dengan Strategi Buzz Group pada Siswa Kelas VIII SMPN 1 Praya Tahun Pelajaran 2018/2019?

\section{Tujuan Penelitian}

Berdasar atas rumusan masalah di atas, maka tujuan dilaksanakan penelitian ini adalah: Untuk Meningkatkan Hasil Belajar Bahasa Indonesia Materi Teks Eksposisi dalam Media Masa dengan Strategi Buzz Group pada Siswa Kelas VIII SMPN 1 Praya Tahun Pelajaran 2018/2019

\section{Manfaat Penelitian}

Adapun manfaat dari penelitian sebagai umbangan pemikiran bagi guru Bahasa Indonesia dalam mengajar dan meningkatkan pemahaman siswa belajar Bahasa Indonesia.

\section{LANDASAN TEORI DAN KAJIAN PUSTAKA}

Pengertian Strategi Buzz roup

Teknik kelompok Buzz sangat mirip dengan metode huddle. Kedua-duanya merupakan alat untuk membagi kelompok diskusi besar menjadi kelompok-kelompok kecil. Dan teknik ini dikemukakan oleh pendidik dan ahli sosiologi Morgan, et 
al., 1976.

Srategi Buzz Group merupakan diskusi kelas yang didalamnya dibagi kedalam kelompok-kelompok kecil untuk melaksanakan diskusi singkat tentang suatu problem.

Mendefinisikan buzz group sebagai suatu kelompok besar dibagi menjadi beberapa kelompok kecil yang terdiri atas 4-5 orang. Menurut (Trianto) Buzz group sebagai suatu kelompok aktif yang terdiri dari 3-6 siswa untuk mendiskusikan ide siswa pada materi pelajaran.

Strategi buzz group adalah suatu kelompok dibagi kedalam beberapa kelompok kecil (sub groups) yang masingmasing terdiri dari 3-6 orang dalam tempo yang singkat, untuk mendiskusikan suatu topik/memecahkan suatu masalah seorang juru bicara ditunjuk untuk menyampaikan hasil diskusi kelompok masing-masing kepada sidang lengkap seluruh kelompok.

Bentuk diskusi ini terdiri dari kelas yang di bagi-bagi menjadi kelompokkelompok kecil yang terdiri 3-4 peserta. Tempat duduk di atur sedemikian rupa agar para siswa dapat bertukar pikiran dan bertatap muka dengan mudah. Diskusi ini biasanya diadakan di tengah-tengah pelajaran atau diakhir pelajaran dengan maksud untuk memperjelas dan mempertajam kerangka bahan pelajaran atau sebagai jawaban terhadap pertanyaan-pertanyaan yang muncul.

Dari berbagai penelitian di atas, dapat peneliti simpulkan bahwa strategi buzz group adalah strategi kelompok kecil yang terbentuk dari tiap- tiap kelompok terdiri dari 3-6 siswa, yang masing-masing dari tiap-tiap kelompok menunjuk satu orang untuk melaporkan hasil diskusi kepada kelompok besar.

Diskusi kelompok kecil ini diadakan di tengah atau diakhir pelajaran dengan maksud menajamkan kerangka bahan pelajaran, memperjelas bahan pelajaran atau menjawab pertanyaan-pertanyaan.

Hasil belajar yang di harapkan ialah agar segenap individu dapat membandingkan persepsinya yang mungkin berbeda-beda tentang bahan pelajaran, membandingkan interprestasi dan informasi yang di peroleh

masing-masing. Dengan demikian masingmasing individu dapat saling memperbaiki pengertian, persepsi informasi, interprestasi, sehingga dapat di hindarkan kekeliruankekeliruan.

\section{Tujuan Pembelajaran Strategi Buzz Group}

Tujuan strategi buzz group adalah untuk memperoleh informasi, untuk memecahkan suatu masalah atau mendiskusikan suatu masalah. Suatu pembelajaran dengan menggunakan strategi buzz group di harapkan dapat menggali informasi sendiri melalui diskusi. Dengan diskusi siswa dapat melatih diri untuk memecahkan masalah, sehingga pembelajaran yang diharapkan dengan pendekatan PAKEM (pembelajaran aktif, kreatif, efektif, dan menyenangkan) dapat terwujud.

Kelebihan dan kelemahan strategi buzz group

Setiap metode pembelajaran selalu mempunyai kelebihan dan kekurangan. Adapun kelebihan dari metode buzz group antara lain: a) Mendorong peserta yang malumalu, b) Menciptakan suasana yang menyenangkan, c) Memungkinkan pembagian tugas kepemimpinan, d) Menghemat waktu, e) Memupuk kepemimpinan, f) Memungkinkan pengumpulan pendapat, g) Dapat dipakai bersama metode lainnya, h) Memberi variasi

Adapun kelemahan dalam diskusi buzz group yaitu : a) Kemungkinan terjadi kelompok yang terdiri dari orang yang tidak tahu apa-apa, b) Dapat memboroskan waktu, terutama bila terjadi hal-hal yang bersifat negative, c) Perlu belajar apabila ingin memperoleh hasil yang maksimal, d) Kemungkinan mendapatkan pemimpin yang lemahLaporan hasil diskusi e) kemungkinan tidak tersusun dengan baik.

Pelaksanaan strategi buzz group dalam pelajaran Bahasa Indonesia.

$$
\text { Pada pelaksanaan diskusi }
$$

kelompok kecil, guru dapat memimpin sendiri jalannya diskusi atas kesepakatan bersama, baik di pimpin oleh guru sendiri 
atau para peserta. Perlu kiranya di tunjuk seorang atau beberapa pencatat (notulis) diskusi. Notulis di perlukan karena pokokpokok masalah yang di anggap penting dari seluruh pembicaraan selama diskusi berlangsung harus di catat dengan sebaikbaiknya.

Susunan dari strategi buzz group ini memungkinkan guru untuk melakukan diskusi atau untuk menyusun permainan peran, berdebat atau observasi dari kreatifitas kelompok. Guru dapat meletakkan meja pertemuan di tengahtengah, yang di kelilingi oleh kursi-kursi pada sisi luar..

\section{Materi pembelajaran Bahasa Indonesia}

Teks Eksposisi dalam Media Massa

Kamu tentu senang membaca surat kabar atau majalah. Di media massa kamu mudah mendapatkan teks eksposisi. Kalau ingin mengenal lebih dekat dengan teks tersebut, sesungguhnya dalam percakapan sehari-hari pun dengan mudah kamu mendapatkannya. Ketika menyampaikan uraian dan di dalamnya terdapat banyak pendapat pribadi dengan tujuan untuk meyakinkan orang, berarti kamu sedang menyampaikan teks eksposisi. Pada saat berdiskusi pun demikian; pernyataan pernyataan yang berisi pendapatlah yang sering kamu lontarkan. Nah, sekarang kamu tidak lagi asing dengan teks tersebut, bukan?

\section{Kaidah Kebahasaan Teks Eksposisi}

Perhatikan kata-kata yang digunakan dalam teks eksposisi. Misalnya, teks berjudul "Nasib Hutan Kita Semakin Suram". Teks tersebut pun memiliki kaidah kaidah kebahasaan yang khusus, sebagai berikut. 1) Menggunakan kata-kata teknis atau peristilahan yang berkenaan dengan topik yang dibahas. Dengan topik kehutanan yang menjadi fokus pembahasannya, istilah-istilah yang muncul dalam teks tersebut adalah penebangan liar, hutan lindung, hutan alam, hutan rawa gambut, dan sektor kehutanan. 2) Menggunakan kata-kata yang menunjukkan hubungan argumentasi (kausalitas). Misalnya, jika, sebab, karena, dengan demikian, akibatnya oleh karena itu. Selain itu, dapat pula digunakan kata-kata yang menyatakan hubungan kronologis (keterangan waktu) ataupun kata kata yang menyatakan perbandingan/pertentangan, seperti sebelum itu, kemudian, pada akhirnya, sebaliknya, berbeda halnya, namun. 3) Menggunakan kata-kata kerja mental (mental verba), seperti diharapkan, memprihatinkan, memperkirakan, mengagumkan, menduga, berpendapat, berasumsi, dan menyimpulkan. 4) Menggunakan kata-kata perujukan, seperti berdasarkan data. . ., merujuk pada pendapat. . . 5) Menggunakan kata-kata persuasif, seperti hendaklah, sebaiknya, diharapkan, perlu, harus. Selain itu, teks eksposisi lebih sering menggunakan kata-kata denotatif, yakni kata yang bermakna sebenarnya. Kata itu belum mengalami perubahan ataupun penambahan makna.

\section{METODOLOGI PENELITIAN}

\section{Bentuk Penelitian Tindakan}

PTK dapat membantu dalam pengembangan kompetensi guru dalam penyelesaikan masalah. Dalam PTK pembelajaran mencakup kualitas isi, efisiensi, dan efektivitas pembelajaran, proses, dan hasil belajar siswa, serta peningkatan kemampuan pembelajaran akan berdampak pada peningkatan kompetensi kepribadian, sosial, dan profesional guru (Prendergast, 2002).

Cole dan Knowles (Prendergast (2002:3-4) menyatakan bahwa, penelitian tindakan kelas dapat mengarahkan para guru untuk melakukan kolaborasi, efleksi, dan bertanya satu dengan yang lain dengan tujuan tidak hanya tentang program dan metode mengajar, tetapi juga membantu para guru mengembangkan hubungan-hubungan personal. Pernyataan Knowles tersebut juga didukung oleh Noffke (Prendergast (2002:5), bahwa penelitian tindakan kelas dapat mendorong para guru melakukan refleksi terhadap praktek pembelajarannya untuk membangun pemahaman mendalam dan mengembangkan hubungan-hubungan personal dan sosial antar guru. Whitehead (1993) menyatakan, bahwa penelitian tindakan kelas dapat memfasilitasi guru untuk mengembangkan pemahaman tentang pedagogi dalam rangka memperbaiki pemberlajarannya.

Tempat, Waktu dan Subyek Penelitian 
Penelitian ini bertempat di SMP Negeri 1 Praya dilaksanakan pada bulan september semester ganjil tahun pelajaran 2018/2019, pada siswa-siswi SMP Negeri 1 Praya Kelas VIII tahun materi membuat sebuah paragraf.

\section{Rancangan Penelitian}

Sesuai dengan jenis penelitian yang dipilih, yaitu penelitian tindakan, maka penelitian ini menggunakan model penelitian tindakan dari kemmis dan Taggert (dalam Arikunto, Suharsimi, 2002: 83) yaitu berbentuk spiral dari siklus yang satu ke siklus yang berikutnya. Setiap siklus meliputi planning (rencana), action (tindakan), observation (pengamatan), dan reflection (refleksi). Langkah pada siklus berikutnya adalah perencanaan yang sudah direvisi, tindakan, pengamatan, dan refleksi. Sebelum masuk pada siklus I dilakukan tindakan pendahuluan yang berupa identifikasi permasalah. Siklus spiral dari tahap-tahap penelitian tindakan kelas dapat dilihat pada gambar berikut :

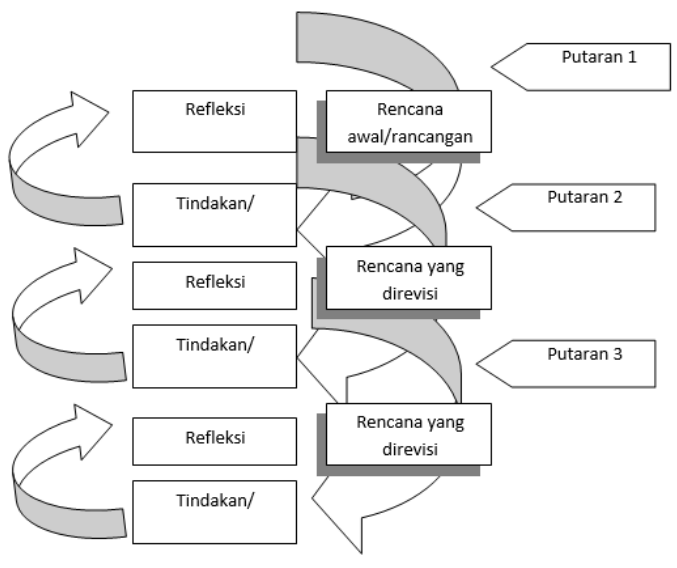

\section{Instrumen Penelitian}

Instrumen yang digunakan dalam penelitian ini terdiri dari: Silabus, Rencana Pelajaran (RP), Lembar Kegiatan Siswa (LKS), Tes formatif

Validitas Tes

Validitas butir soal atau validitas item digunakan untuk mengetahui tingkat kevalidan masing-masing butir soal. Sehingga dapat ditentukan butir soal yang gagal dan yang diterima. Tingkat kevalidan ini dapat dihitung dengan korelasi Product Moment:

$$
r_{x y}=\frac{N \sum X Y-\left(\sum X\right)\left(\sum Y\right)}{\sqrt{\left\{N \sum X^{2}-\left(\sum X\right)^{2}\right)\left(N \sum Y^{2}-\left(\sum Y\right)^{2}\right\}}}
$$

(Suharsimi Arikunto, 2001: 72)

Dengan:

$\mathrm{r}_{\mathrm{xy}} \quad$ : Koefisien korelasi product moment

$\mathrm{N}$ : Jumlah peserta tes

$\Sigma \mathrm{Y} \quad$ : Jumlah skor total

$\Sigma X \quad$ : Jumlah skor butir soal

$\Sigma \mathrm{X}^{2} \quad$ : Jumlah kuadrat skor butir soal

$\Sigma X Y$ : Jumlah hasil kali skor butir soal

Reliabilitas

Reliabilitas butir soal dalam penelitian ini menggunakan rumus belah dua sebagai berikut:

$$
r_{11}=\frac{2 r_{1 / 21 / 2}}{\left(1+r_{1 / 21 / 2}\right)}(\text { Suharsimi Arikunto, }
$$

2001: 93)

Dengan:

$\mathrm{r}_{11} \quad$ : Koefisien reliabilitas yang sudah disesuaikan

$\mathrm{r}_{1 / 21 / 2}$ : Korelasi antara skor-skor setiap belahan tes

Kriteria reliabilitas tes jika harga $\mathrm{r}_{11}$ dari perhitungan lebih besar dari harga $r$ pada tabel product moment maka tes tersebut reliabel.

Taraf Kesukaran

Bilangan yang menunjukkan sukar dan mudahnya suatu soal adalah indeks kesukaran. Rumus yang digunakan untuk menentukan taraf kesukaran adalah:

$$
P=\frac{B}{J_{S}} \quad \text { (Suharsimi Arikunto, 2001: }
$$

208)

Dengan:

P : Indeks kesukaran

B : Banyak siswa yang menjawab soal dengan benar

Js : Jumlah seluruh siswa peserta tes

Kriteria untuk menentukan indeks kesukaran soal adalah sebagai berikut:

$$
\begin{array}{ll}
\text { - } & \text { Soal dengan } P=0,000 \text { sampai } \\
0,300 \text { adalah sukar } & \\
\text { Soal dengan } P=0,301 \text { sampai } \\
\text { 0,700 adalah sedang } \\
\text { Soal dengan } P=0,701 \text { sampai } \\
\text { 1,000 adalah mudah }
\end{array}
$$

Daya Pembeda

Daya pembeda soal adalah kemampuan suatu soal untuk membedakan antara siswa yang berkemampuan tinggi dengan siswa yang berkemampuan rendah. Angka yang menunjukkan besarnya daya 
pembeda desebut indeks diskriminasi. Rumus yang digunakan untuk menghitung indeks disriminasi adalah sebagai berikut:

$$
D=\frac{B_{A}}{J_{A}}-\frac{B_{B}}{J_{B}}=P_{A}-P_{B}
$$

(Suharsimi Arikunto, 2001: 211)

\section{Dimana:}

D : Indeks diskriminasi

$\mathrm{B}_{\mathrm{A}} \quad$ : Banyak peserta kelompok atas yang menjawab dengan benar

$\mathrm{B}_{\mathrm{B}} \quad$ : Banyak peserta kelompok bawah yang menjawab dengan benar

$\mathrm{J}_{\mathrm{A}} \quad$ : Jumlah peserta kelompok atas

$\mathrm{J}_{\mathrm{B}} \quad$ : Jumlah peserta kelompok bawah $P_{A}=\frac{B_{A}}{J_{A}}=$ Proporsi peserta kelompok atas

yang menjawab benar.

$$
P_{B}=\frac{B_{B}}{J_{B}}=\text { Proporsi peserta kelompok }
$$

bawah yang menjawab benar

Kriteria yang digunakan untuk menentukan daya pembeda butir soal sebagai berikut:

- $\quad$ Soal dengan $\mathrm{D}=0,000$ sampai 0,200 adalah jelek

- $\quad$ Soal dengan $\mathrm{D}=0,201$ sampai 0,400 adalah cukup

- $\quad$ Soal dengan $D=0,401$ sampai 0,700 adalah baik

- $\quad$ Soal dengan D =0,701 sampai 1,000 adalah sangat baik

\section{Metode Pengumpulan Data}

Data-data yang diperlukan dalam penelitian ini diperoleh melalui observasi pengolahan belajar aktif, observasi aktivitas siswa dan guru, dan tes formatif.

\section{Teknik Analisis Data}

Untuk mengetahui keefektivan suatu metode dalam kegiatan pembelajaran perlu diadakan analisa data. Pada penelitian ini menggunakan teknik analisis deskriptif kualitatif, yaitu suatu metode penelitian yang bersifat menggambarkan kenyataan atau fakta sesuai dengan data yang diperoleh dengan tujuan untuk mengetahui prestasi belajar yang dicapai siswa juga untuk memperoleh respon siswa terhadap kegiatan pembelajaran serta aktivitas siswa selama proses pembelajaran.

$$
\text { Untuk menganalisis tingkat }
$$

keberhasilan atau persentase keberhasilan siswa setelah proses belajar mengajar setiap putarannya dilakukan dengan cara memberikan evaluasi berupa soal tes tertulis pada setiap akhir putaran.

Analisis ini dihitung dengan menggunakan statistik sederhana yaitu:

Untuk menilai ulangan atau tes formatif

Peneliti melakukan penjumlahan nilai yang diperoleh siswa, yang selanjutnya dibagi dengan jumlah siswa yang ada di kelas tersebut sehingga diperoleh rata-rata tes formatif dapat dirumuskan:

$$
\bar{X}=\frac{\sum X}{\sum N}
$$

Dengan :

$\bar{X} \quad=$ Nilai rata-rata

$\Sigma X=$ Jumlah semua nilai siswa

$\Sigma \mathrm{N}=$ Jumlah siswa

Untuk ketuntasan belajar

Ada dua kategori ketuntasan belajar yaitu secara perorangan dan secara klasikal. Berdasarkan petunjuk pelaksanaan belajar mengajar kurikulum 1994 (Depdikbud, 1994), yaitu seorang siswa telah tuntas belajar bila telah mencapai skor $65 \%$ atau nilai 65 , dan kelas disebut tuntas belajar bila di kelas tersebut terdapat $85 \%$ yang telah mencapai daya serap lebih dari atau sama dengan $65 \%$. Untuk menghitung persentase ketuntasan belajar digunakan rumus sebagai berikut:

$$
P=\frac{\sum \text { Siswa.yang.tuntas.belajar }}{\sum \text { Siswa }} \times 100 \%
$$

\section{HASIL PENELITIAN DAN PEMBAHASAN}

\section{Analisa data}

Suatu pokok bahasan atau sub pokok bahasan dianggap tuntas secara klasikal jika siswa yang mendapat nilai 65 lebih dari atau sama dengan $85 \%$, sedangkan seorang siswa dinyatakan tuntas belajar pada pokok bahasan atau sub pokok bahasan tertentu jika mendapat nilai minimal 65 .

Siklus I

Pelaksanaan kegiatan belajar mengajar untuk siklus I dilaksanakan pada bulan september 2018 Kelas VIII jumlah siswa 40 siswa. Dalam hal ini peneliti bertindak sebagai pengajar. Adapun proses 
belajar mengajar mengacu pada rencana pelajaran yang telah dipersiapkan. Pengamatan (observasi) dilaksanakan bersamaan dengan pelaksanaan belajar mengajar. Pada akhir proses belajar mengajar siswa diberi tes formatif I dengan tujuan untuk mengetahui tingkat keberhasilan siswa dalam proses belajar mengajar yang telah dilakukan. Adapun data hasil penelitian pada siklus I adalah sebagai berikut.

Berdasarkan hasil analisa data atas aspek-aspek yang mendapatkan kriteria kurang baik adalah memotivasi siswa, menyampaikan tujuan pembelajran, pengelolaan waktu, dan siswa antusias. Keempat aspek yang mendapat nilai kurang baik di atas, merupakan suatu kelemahan yang terjadi pada siklus I dan akan dijadikan bahan kajian untuk refleksi dan revisi yang akan dilakukan pada siklus II.

Dari hasil analisa data prestasi belajar dapat dijelaskan bahwa dengan menerapkan pembelajaran dengan Metode pembelajaran buzz groub diperoleh nilai ratarata prestasi belajar siswa adalah 64 dan ketuntasan belajar mencapai $62 \%$ atau ada 15 siswa dari 34 siswa sudah tuntas belajar. Hasil tersebut menunjukkan bahwa pada siklus pertama secara klasikal siswa belum tuntas belajar, karena siswa yang memperoleh nilai $\geq$ 65 hanya sebesar $62 \%$ lebih kecil dari persentase ketuntasan yang dikehendaki yaitu sebesar $85 \%$. Hal ini disebabkan karena siswa masih merasa baru dan belum mengerti apa yang dimaksudkan dan digunakan guru dengan menerapkan pembelajaran dengan Metode pembelajaran buzz groub.

Siklus II

Pelaksanaan kegiatan belajar mengajar untuk siklus II dilaksanakan pada tanggal 11 september2018 di Kelas VIII dengan jumlah siswa 40 siswa. Dalam hal ini peneliti bertindak sebagai pengajar. Adapun proses belajar mengajar mengacu pada rencana pelajaran dengan memperhatikan revisi pada siklus I, sehingga kesalahan atau kekurangan pada siklus I tidak terulang lagi pada siklus II. Pengamatan (observasi) dilaksanakan bersamaan dengan pelaksanaan belajar mengajar.
Pada akhir proses belajar mengajar siswa diberi tes formatif II dengan tujuan untuk mengetahui tingkat keberhasilan siswa dalam proses belajar mengajar yang telah dilakukan. Instrumen yang digunakan adalah tes formatif II. Adapun data hasil penelitian pada siklus II adalah sebagai berikut. Dari tabel di atas, tanpak aspek-aspek yang diamati pada kegiatan belajar mengajar (siklus II) yang dilaksanakn oleh guru dengan menerapkan metode pembelajarn kooperatif model Buzz groub mendapatkan penilaian yang cukup baik dari pengamat. Maksudnya dari seluruh penilaian tidak terdapat nilai kurang. Namun demikian penilaian tesebut belum merupakan hasil yang optimal, untuk itu ada beberapa aspek yang perlu mendapatkan perhatian untuk penyempurnaan penerapan pembelajaran selanjutnya. Aspekaspek tersebut adalah memotivasi siswa, membimbing siswa merumuskan kesimpulan/ menemukan konsep, dan pengelolaan waktu.

Dengan penyempurnaan aspekaspek I atas alam penerapan metode pembelajarn Buzz groub diharapkan siswa dapat menyimpulkan apa yang telah mereka pelajari dan mengemukakan pendapatnya sehingga mereka akan lebih memahami tentang apa ynag telah mereka lakukan

Dari hasil pengolahan data diperoleh nilai rata-rata prestasi belajar siswa adalah 71,80 dan ketuntasan belajar mencapai $77 \%$ atau ada 31 siswa dari 22 siswa sudah tuntas belajar. Hasil ini menunjukkan bahwa pada siklus II ini ketuntasan belajar secara klasikal telah mengalami peningkatan sedikit lebih baik dari siklus I. Adanya peningkatan kemampuan berbicara siswa ini karena setelah guru menginformasikan bahwa setiap akhir pelajaran akan selalu diadakan tes sehingga pada pertemuan berikutnya siswa lebih termotivasi untuk belajar. Selain itu siswa juga sudah mulai mengerti apa yang dimaksudkan dan diinginkan guru dengan menerapkan pembelajaran dengan Metode pembelajaran buzz groub ..

Siklus III

Pelaksanaan kegiatan belajar mengajar untuk siklus III dilaksanakan pada tanggal 18 September 2018 di Kelas VIII dengan jumlah siswa 40 siswa. Dalam hal ini 
peneliti bertindak sebagai pengajar. Adapun proses belajar mengajar mengacu pada rencana pelajaran dengan memperhatikan revisi pada siklus II, sehingga kesalahan atau kekurangan pada siklus II tidak terulang lagi pada siklus III. Pengamatan (observasi) dilaksanakan bersamaan dengan pelaksanaan belajar mengajar.

Pada akhir proses belajar mengajar siswa diberi tes formatif III dengan tujuan untuk mengetahui tingkat keberhasilan siswa dalam proses belajar mengajar yang telah dilakukan. Instrumen yang digunakan adalah tes formatif III. Adapun data hasil penelitian pada siklus III adalah sebagai berikut.

Dari hasil analisa data, dapat cermati aspek-aspek yang diamati pada kegiatan belajar mengajar (siklus III) yang dilaksanakan oleh guru dengan menerapkan metode pembelajaran kooperatif model Buzz groub mendapatkan penilaian cukup baik dari pengamat adalah memotivasi siswa, membimbing siswa merumuskan kesimpulan/menemukan konsep, dan pengelolaan waktu.

Penyempurnaan aspek-aspek diatas dalam menerapkan metode pembelajaran kooperatif model Buzz groub diharapkan dapat berhasil semaksimal mungkin.

Berdasarkan tabel di atas diperoleh nilai rata-rata tes formatif sebesar 92 dan dari 40 siswa telah tuntas sebanyak 36 siswa dan 4siswa belum mencapai ketuntasan belajar. Maka secara klasikal ketuntasan belajar yang telah tercapai sebesar 90\% (termasuk kategori tuntas). Hasil pada siklus III ini mengalami peningkatan lebih baik dari siklus II. Adanya peningkatan kemampuan berbicara pada siklus III ini dipengaruhi oleh adanya peningkatan kemampuan guru dalam menerapkan pembelajaran dengan metode pembelajaran buzz groub sehingga siswa menjadi lebih terbiasa dengan pembelajaran seperti ini sehingga siswa lebih mudah dalam memahami materi yang telah diberikan.

\section{Pembahasan}

Ketuntasan Kemampuan berbicara Siswa

Melalui hasil penelitian ini menunjukkan bahwa pembelajaran dengan Metode pembelajaran buzz groub memiliki dampak positif dalam meningkatkan prestasi belajar siswa. Hal ini dapat dilihat dari semakin mantapnya pemahaman siswa terhadap materi yang disampaikan guru (ketuntasan belajar meningkat dari siklus I, II, dan III) yaitu masing-masing $62 \%, 77 \%$, dan 90\%. Pada siklus III ketuntasan belajar siswa secara klasikal telah tercapai.

Kemampuan Guru dalam Mengelola Pembelajaran

Berdasarkan analisis data, diperoleh aktivitas siswa dalam proses belajar mengajar dengan menerapkan model pengajaran Metode pembelajaran buzz groub dalam setiap siklus mengalami peningkatan. Hal ini berdampak positif terhadap prestasi belajar siswa yaitu dapat ditunjukkan dengan meningkatnya nilai rata-rata siswa pad setiap siklus yang terus mengalami peningkatan.

Aktivitas Siswa Dalam Pembelajaran

Berdasarkan analisis data, diperoleh aktivitas siswa dalam proses pembelajaran Bahasa Indonesia dengan model pengajaran Metode pembelajaran buzz groub yang paling dominan adalah, mendengarkan/memperhatikan penjelasan guru, dan diskusi antar siswa/antara siswa dengan guru. Jadi dapat dikatakan bahwa aktivitas siswa dapat dikategorikan aktif

Sedangkan untuk aktivitas guru selama pembelajaran telah melaksanakan langkahlangkah kegiatan belajar mengajar dengan menerapkan pengajaran konstekstual model pengajaran berbasis masalah dengan baik. Hal ini terlihat dari aktivitas guru yang muncul di antaranya aktivitas membimbing dan mengamati siswa dalam menemukan konsep, menjelaskan materi yang sulit, memberi umpan balik/evaluasi/tanya jawab dimana prosentase untuk aktivitas di atas cukup besar.

\section{SIMPULAN}

Berdasarkan hasil penelitian yang telah dipaparkan selama tiga siklus, hasil seluruh pembahasan serta analisis yang telah dilakukan dapat disimpulkan sebagai berikut:

1. Model pengajaran Metode pembelajaran buzz groub dapat meningkatkan kualitas pembelajaran Bahasa Indonesia.

2. Pembelajaran dengan Metode pembelajaran buzz groub memiliki dampak positif dalam meningkatkan 
prestasi belajar siswa yang ditandai dengan peningkatan ketuntasan belajar siswa dalam setiap siklus, yaitu siklus I $(62 \%)$, siklus II (77\%), siklus III $(90 \%)$.

3. Model pengajaran Metode pembelajaran buzz groub dapat menjadikan siswa merasa dirinya mendapat perhatian dan kesempatan untuk menyampaikan pendapat, gagasan, ide dan pertanyaan.

4. Siswa dapat bekerja secara mandiri maupun kelompok, serta mampu mempertanggungjawabkan segala tugas individu maupun kelompok.

5. Penerapan pembelajaran dengan Metode pembelajaran buzz groub mempunyai pengaruh positif, yaitu dapat meningkatkan kreatifitas belajar siswa.

\section{DAFTAR PUSTAKA}

Abror, Rahman, 1993. Psikologi Pendidikan,

Yogyakarta : Tiara Wacana

A Partanto, Pius, dan All Barry, M. Dahlan, 2001. Kamus Ilmiah Populer, Surabaya : Arkola

Arsyad, Azhar, 2008. Media Pembelajaran, Jakarta : Raja Grafindo Persada

Arikunto, Suharsimi, 2006. Prosedur Penelitian Suatu Pendekatan Praktek, Jakarta : Rineka Cipta

Faisol, Sanapiah, 1995. Format-Format penelitian Kualitatif Dasar-Dasar Dan Aplikasi, Jakarta: Rajawali Pers

Hadi, Sutrisno, Metodologi Research, Jilid 3

Hasbullah, 2006. Dasar-dasar Ilmu Pendidikan, Jakarta : Raja Grafindo Persada

Hasibuan dan Moedjiono, 1995. Proses Belajar Mengajar, Bandung : PT. Remaja

Imron, Ali, 1996. Belajar Dan Pembelajaran, Jakarta : Pustaka Jaya Rosdakarya

Isjoni, 2009. Coopertive Learning, Bandung : Alfabeta

John. M.Echols, et al, 1996. Kamus InggrisIndonesia, Jakarta : Gramedia

Kenz, http:/blok. Kenz. O. it.26. 05. 2007:58:44

Lexy J, Moleong, 2001. Metodologi Penelitian Kualitatif, PT Remaja
Rosda Karya M Amirin, Tatang, 1995. Menyusun Rencana Penelitian, Jakarta: Raja Grafindo Persada

Mardalis, 1995. Metode Penelitian Suatu Pendekatan Proporsional, Jakarta: Bumi

Aksara

Margono, 1997. Metode Penelitian, Jakarta : Rineka Cipta

M. Nasir, 1988. Metode Penelitian, Jakarta : Ghalia

Mulyasa, E, 2003. Kurikulum Berbasis Kompetensi, Karakteristik Dan Implementasi, Bandung: Rosdakarya

Narkubo, Cholid, dan Ahmadi, Abu, 1995. Metode Penelitian, Jakarta: Bumi Aksara

Nasution, 1995. Didaktik Asas-asas Mengajar, Jakarta: Bumi Aksara

Nawawi, Hadari, dan Nawawi, M. Martini, 1995. Instrumen Penelitian Bidang Sosial, Yogyakarta: Gajah Mada University Press

Poewardaminta, Kamus Besar Bahasa Indonesia

Purwanto, Ngalim, 2000. Psikologi Pendidikan, Bandung : PT Remaja Rosdakarya

Sanjaya, Wina, Strategi Pembelajaran: Berorientasi Standar Proses Pendidikan, Jakarta: Kencana Predia Media Group

Sardiman, 2018, Interaksi Dan Motivasi Belajar Mengajar, Jakarta : PT Raja Grafindo Persada

Soemanto, Wasty, 1998. Psikologi Pendidikan, Jakarta : Rineka Cipta

Slameto, 2001. Proses Belajar Mengajar Dalam SKS, Jakarta : Bumi Aksara

Sumanto, 1995 Metodologi Penelitian Sosial Dan Pendidikan, Yogyakarta : Andi Offset

Suprijanto, 2007. Pendidikan Orang Dewasa Dari Teori Hingga Aplikasi, Jakarta: Bumi Aksara

Surjadi, 1989. Membuat Siswa Aktif, Bandung: Bandar Maju

Trianto, 2007. Model Pembelajaran Inovatif, Jakarta : Prestasi Pustaka 
Warsito, Hermawan, 1992. Pengantar Metodologi Penelitian, Jakarta : PT Gramedia Pustaka Utama

Yulis, Rama, 2002. Ilmu Pendidikan Islam, Jakarta : Kalam Mulia

Zaini, Hisyam, 2008. Strategi Pembelajaran Aktif, Yogyakarta : Pustaka Insan Madani 